\title{
Current understanding and biotechnological application of the bacterial diterpene synthase CotB2
}

\author{
Ronja Driller ${ }^{1,2,3}$, Daniel Garbe ${ }^{4}$, Norbert Mehlmer ${ }^{4}$, Monika Fuchs ${ }^{4}$, Keren Raz ${ }^{5}$, \\ Dan Thomas Major ${ }^{*}$, Thomas Brück ${ }^{*}$ and Bernhard Loll ${ }^{*}$
}

\section{Review}

\section{Address:}

${ }^{1}$ Institute of Chemistry and Biochemistry, Laboratory of Structural Biochemistry, Freie Universität Berlin, Takustr. 6, 14195 Berlin, Germany, ${ }^{2}$ present address: Department of Molecular Biology and Genetics, Aarhus University, Gustav Wieds Vej 10, 8000 Aarhus C, Denmark, ${ }^{3}$ present address: Danish Research Institute of Translational Neuroscience - DANDRITE, Nordic-EMBL Partnership for Molecular Medicine, Aarhus C, Denmark, ${ }^{4}$ Werner Siemens Chair of Synthetic Biotechnology, Dept. of Chemistry, Technical University of Munich (TUM), Lichtenbergstr. 4, 85748 Garching, Germany and ${ }^{5}$ Department of Chemistry, Bar-Ilan University, Ramat-Gan 52900, Israel

\section{Email:}

Dan Thomas Major* - majort@biu.ac.il; Thomas Brück* brueck@tum.de; Bernhard Loll ${ }^{*}$ - loll@chemie.fu-berlin.de

${ }^{*}$ Corresponding author

\section{Keywords:}

biotechnology; CotB2; crystal structure; cyclooctatin; diterpene; reaction mechanism; terpene synthase

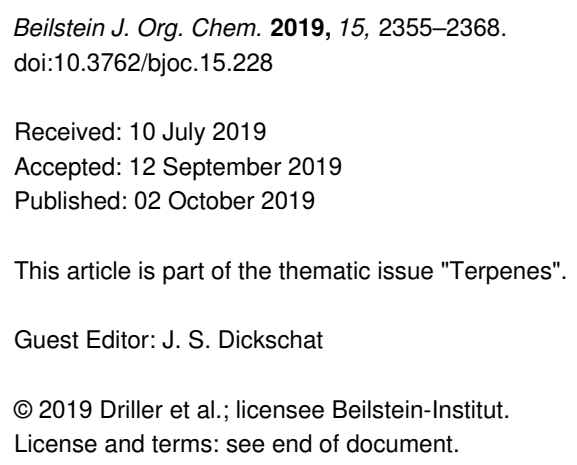

\begin{abstract}
CotB2 catalyzes the first committed step in cyclooctatin biosynthesis of the soil bacterium Streptomyces melanosporofaciens. To date, CotB2 represents the best studied bacterial diterpene synthase. Its reaction mechanism has been addressed by isoptope labeling, targeted mutagenesis and theoretical computations in the gas phase, as well as full enzyme molecular dynamic simulations. By X-ray crystallography different snapshots of CotB2 from the open, inactive, to the closed, active conformation have been obtained in great detail, allowing us to draw detailed conclusions regarding the catalytic mechanism at the molecular level. Moreover, numerous alternative geranylgeranyl diphosphate cyclization products obtained by CotB2 mutagenesis have exciting applications for the sustainable production of high value bioactive substances.
\end{abstract}

\section{Introduction}

Terpenes represent one of the most diverse groups of natural biomolecules [1-3]. Sesqui- and diterpenes are a diverse class of secondary metabolites derived predominantly from plants, marine invertebrates, fungi and some prokaryotes [4-8]. Proper- ties of these natural products include antitumor, anti-oxidant, anti-inflammatory, antiviral, antimalarial, antibiotic, neuroprotective and even insecticidal activities, which makes these compounds high-value commercial targets for the chemical and 
pharmaceutical industry [9,10]. Structural diversity of diterpenes is created by the terpene synthase (TPS) enzyme family, which use acyclic isoprenoid precursors to generate a vast number of (poly)cyclic hydrocarbon scaffolds. Remarkably, this complex chemical reaction, comprising changes in bonding, hybridization as well as the introduction of specific stereochemistry, is performed in a single reaction cascade without consumption of a cofactor [11]. In this review we will focus particularly on bacterial diterpene synthases, in context with other sesqui- and ditperpene synthases of bacterial, fungal and plant origin.

The initial step in diterpene biosynthesis (Figure 1) is the incremental condensation of dimethylallyl diphosphate (1) and isopentylen diphosphate (2) [12] to the acyclic terpene synthase substrate geranylgeranyl diphosphate 3 (GGDP) [1,13-16]. Following initial substrate binding and folding in a product-like conformation, the cyclization reaction can be subdivided into three steps: (1) generation of a reactive allyl carbocation as a result of heterolytic cleavage of the pyrophosphate-hydrocarbon bond or protonation of a double bond, (2) propagation of the carbocation along the forming terpene skeleton as a result of ring formations, hydride and/or methyl shifts, de- and reprotonation of intermediates, the creation of a terminal carbocation (3) and finally the quenching of the carbocation by a base or water $[16,17]$.

TPSs can be divided into two distinct classes, which are distinguished by their substrate activation mechanism. Whereas ionization of an isoprenoid diphosphate is caused by hydrolysis of the pyrophosphate by a trinuclear metal cluster in class I terpenoid cyclases, class II reactions proceed via a protonation of the terminal carbon-carbon double bond of an isoprenoid substrate [3]. In addition to the differences in the activation mechanism, the two classes of TPSs have an unrelated overall fold. Class I TPSs establish an $\alpha$-helical bundle fold [18] and are structurally related to the isoprenyl diphosphate synthases such as the farnesyl (C15) or geranylgeranyl (C20) diphosphate synthase, which generate the substrates of sesqui- and diterpene synthases, respectively. In bacteria, diterpene synthases almost exclusively belong to class I TPSs. A few exceptions exist, for example the terpentedienyl-diphosphate synthase from Kitasatospora griseola [19], which belongs to class II, and PtmT1 from Streptomyces platensis in the platensimycin gene cluster [20], which is neither characteristic for class I nor class II. In fungi and plants, they can be both class I or class II TPSs and even mixed class I/II [21]. Class I TPSs harbor two distinct catalytic motifs, which are crucial for binding and correctly positioning the substrate for catalysis, the aspartate-rich motif (DDxxD) and the NSE/DTE motif, that bind to three $\mathrm{Mg}^{2+}$ ions $[1,22]$. Notably, the PtmT1 diterpene synthase from S. platensis lacks both catalytic motifs [20,23]. The NSE/DTE motif illustrates the distribution of DTE motifs, which are predominantly found in plant TPSs, and NSE motifs, which are more common in bacterial and fungal TPSs. For the description of the bacterial TPS CotB2, we will therefore refer to the NSE motif only.

Using host microorganisms, such as bacteria or baker's yeast for the heterologous synthesis of terpenes increases the sustainability of bioactive terpene production by saving resources, as the production host can be fed with residual organic waste streams, such as milling or forestry waste. Additionally, the heterologous terpene production minimizes waste generation as the targeted production of a single compound reduces extraction and purification steps [24,25]. Additionally, heterologous production enables protein engineering to optimize product ratios or to alter the native product portfolio of the enzyme $[9,26,27]$. Furthermore, production by engineered microorganisms considerably reduces the cost compared to total chemical synthesis or extraction from natural sources, since the target compounds are produced from inexpensive carbon sources. Prominent examples of optimized terpene production pathways in E. coli are taxadiene, a precursor of the anticancer drug taxol

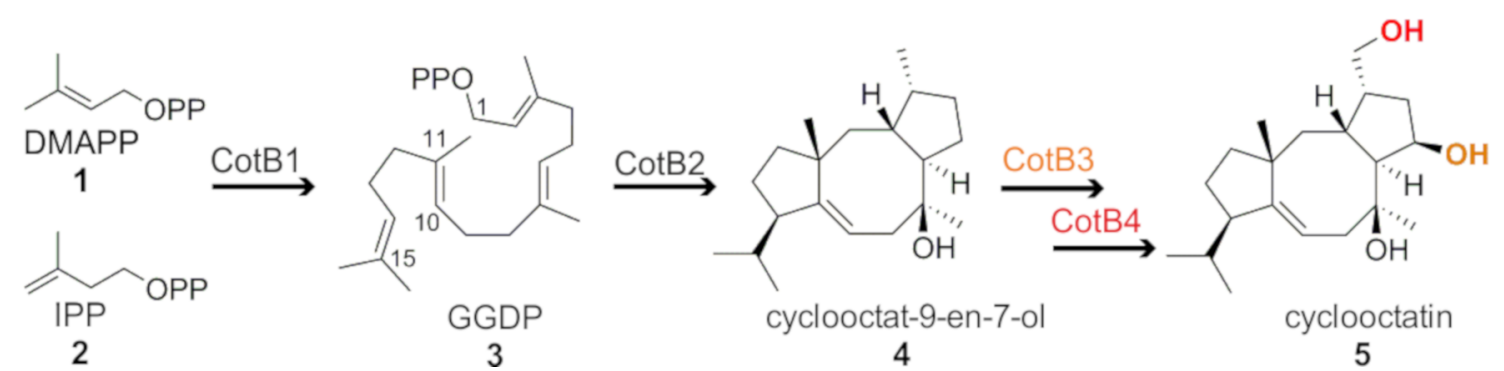

Figure 1: CotB1 synthesizes geranylgeranyl diphosphate (GGDP) 3 from the substrates dimethylallyl diphosphate (DMAPP) 1 and isopentenyl diphosphate (IPP) 2. The acyclic substrate GGDP (3) is stereospecifically cyclized by CotB2 to cyclooctat-9-en-7-ol (4), with a fusicoccane 5-8-5 fused ring system. Two cytochrome P450 enzymes, CotB3 and CotB4, subsequently functionalize cyclooctat-9-en-7-ol (4) to the bioactive compound cyclooctatin (5). 
[28], amorpha-4,11-diene, an antimalarial drug precursor [29], and cyclooctatin [30].

The scope of this review encompasses a detailed consideration of the cyclooctatin biosynthetic gene cluster in particular the TPS CotB2 from the soil bacterium Streptomyces melanosporofaciens MI614-43F2 (Figure 1) [31]. Cyclooctatin 5, with its distinct 5-8 -5 ring motif, belongs to the fusicoccane diterpenoids that encompass a wide range of bioactivities, such as bacteriostatic, fungicidal and tumorstatic effects [32]. A key player in the biosynthesis of cyclooctatin $\mathbf{5}$ is the bacterial diterpene synthase CotB2.

Different research teams have investigated CotB2 by means of biochemical [30,31,38], biophysical [33-35], structural biology [36-39] and computational modeling approaches [35,37,39,40], revealing a rather unusual reaction mechanism. Given the diverse bioactivities of cyclooctatin $\mathbf{5}$, CotB2 is of biotechnological relevance as well. Cyclooctatin $\mathbf{5}$ can be manufactured biotechnologically in E. coli in milligram scales [26,30], which is important for an industrial application. Within the subsequent paragraphs, we would like to summarize the current understanding of the unusual reaction mechanism and the biotechnological applications.

\section{Review}

\section{The cyclooctatin biosynthetic gene cluster}

The cyclooctatin gene cluster from the soil bacterium S. melanosporofaciens MI614-43F2 comprises four enzymes: GGDP synthase (CotB1), a diterpene cyclase (CotB2) and two P450 cytochromes (Figure 1) [31]. The cyclization of GGDP 3 to cyclooctat-9-en-7-ol (4) is performed by the TPS CotB2. Compound $\mathbf{4}$ is further decorated with two hydroxy functions introduced by two P450 cytochromes, CotB3 and CotB4, to cyclooctatin (5). Depending on the functionalization of the ring system, the compounds demonstrate a broad diversity of biological activities, among others fungicidal or tumor static [32,4345]. Cyclooctatin (5) inhibits a lysophospholipase, which catalyzes the hydrolysis of the fatty acid ester bonds of lysophospholipids [31,41]. Moreover, cyclooctatin (5) was shown to be effective against Plasmodium falciparum with an $\mathrm{IC}_{50}$ of $7.14 \mu \mathrm{g} / \mathrm{mL}$ along with very low cytotoxicity [42].

CotB2 belongs to the class of cyclopentane-forming diterpene synthases [46], a class of enzymes that is widely distributed among plants, fungi and bacteria. CotB2 has evolved to convert the acyclic, achiral substrate GGDP to the 5-8-5 ring motif of cyclooctat-9-en-7-ol that contains six chiral stereocenters. Hence, CotB2 has been fine tuned to perform a highly specific regio- and stereochemical reaction. The cyclization mechanism of CotB2 has been investigated extensively in recent years. By isotope labeling and NMR spectroscopic investigations [35], it has been shown that $\mathrm{CotB} 2$ catalyzes the complex regio- and stereospecific cyclization reaction with an unusual carbon-carbon bond rearrangement. Hong and Tantillo performed the first theoretical study of the reaction mechanism in CotB2 via gas phase density functional theory (DFT) calculations [33]. Simultaneously, Sato et al. also studied the CotB2 reaction mechanism in the gas phase using DFT, combined with experimental deuterium labeling [34]. Another important step towards a deeper understanding of the cyclization mechanism was the availability of crystal structures (Table 1) revealing structural snapshots along the reaction trajectory commencing with the open, inactive conformation completing with the closed, active conformation of CotB2. [36-38].

\section{Overall structure of CotB2 ${ }^{\mathrm{wt}}$ in the open, inactive conformation}

The structure of CotB2 ${ }^{\mathrm{wt}}$ (PDB-ID 4OMG [38] and PDB-ID 5 GUC [36]) is complete, except for the $15 \mathrm{~N}$-terminal and 12 C-terminal residues. CotB2 consists of ten core $\alpha$-helices (A to $\mathrm{J})$ that are connected by short loop segments and additional five short $\alpha$-helices ( $\alpha 1$ to $\alpha 5$; (Figure 2A and B)). CotB2 resembles the classical $\alpha$-helical fold of TPSs [18] with significant differences in its primary sequence compared to other TPSs. The core $\alpha$-helices surround a large, deep cleft, which

\begin{tabular}{|c|c|c|c|c|}
\hline protein/variant & PDB-ID & conformation & ligands & reference \\
\hline CotB2wt & 4OMG & open & - & [38] \\
\hline CotB2 $^{\text {wt }}$ & $5 G U C$ & open & - & {$[36]$} \\
\hline CotB2 ${ }^{\mathrm{F} 149 \mathrm{~L}}$ & $4 \mathrm{OMH}$ & open & - & [38] \\
\hline $\operatorname{CotB}^{\Delta C}$ & $6 G G K$ & open & - & {$[37,39]$} \\
\hline CotB2 ${ }^{\mathrm{F} 107 \mathrm{~A}} \cdot \mathrm{Mg}^{2+}{ }_{\mathrm{B}}$ & $6 G G L$ & intermediate & $1 \mathrm{Mg}^{2+}$ & {$[37,39]$} \\
\hline CotB2 ${ }^{\text {wt. }} \cdot \mathrm{Mg}^{2+}{ }_{B} \cdot G G S D P$ & 5GUE & intermediate & $1 \mathrm{Mg}^{2+}$, geranyl geranyl thiodiphosphate (GGSDP) & [36] \\
\hline CotB2 ${ }^{\text {wt. }} \cdot \mathrm{Mg}^{2+}{ }_{3} \cdot \mathrm{F}$-Dola & $6 \mathrm{GGI}$ & closed & $3 \mathrm{Mg}^{2+}$, diphosphate, 2-fluoro-3,7,18-dolabellatriene & {$[37,39]$} \\
\hline CotB2 $^{\text {wt. }} \cdot \mathrm{Mg}^{2+}{ }_{3} \cdot \mathrm{AHD}$ & 6GGJ & closed & $3 \mathrm{Mg}^{2+}$, 4-amino-1-hydroxy-1-phosphonobutyl phosphonic acid & {$[37,39]$} \\
\hline
\end{tabular}




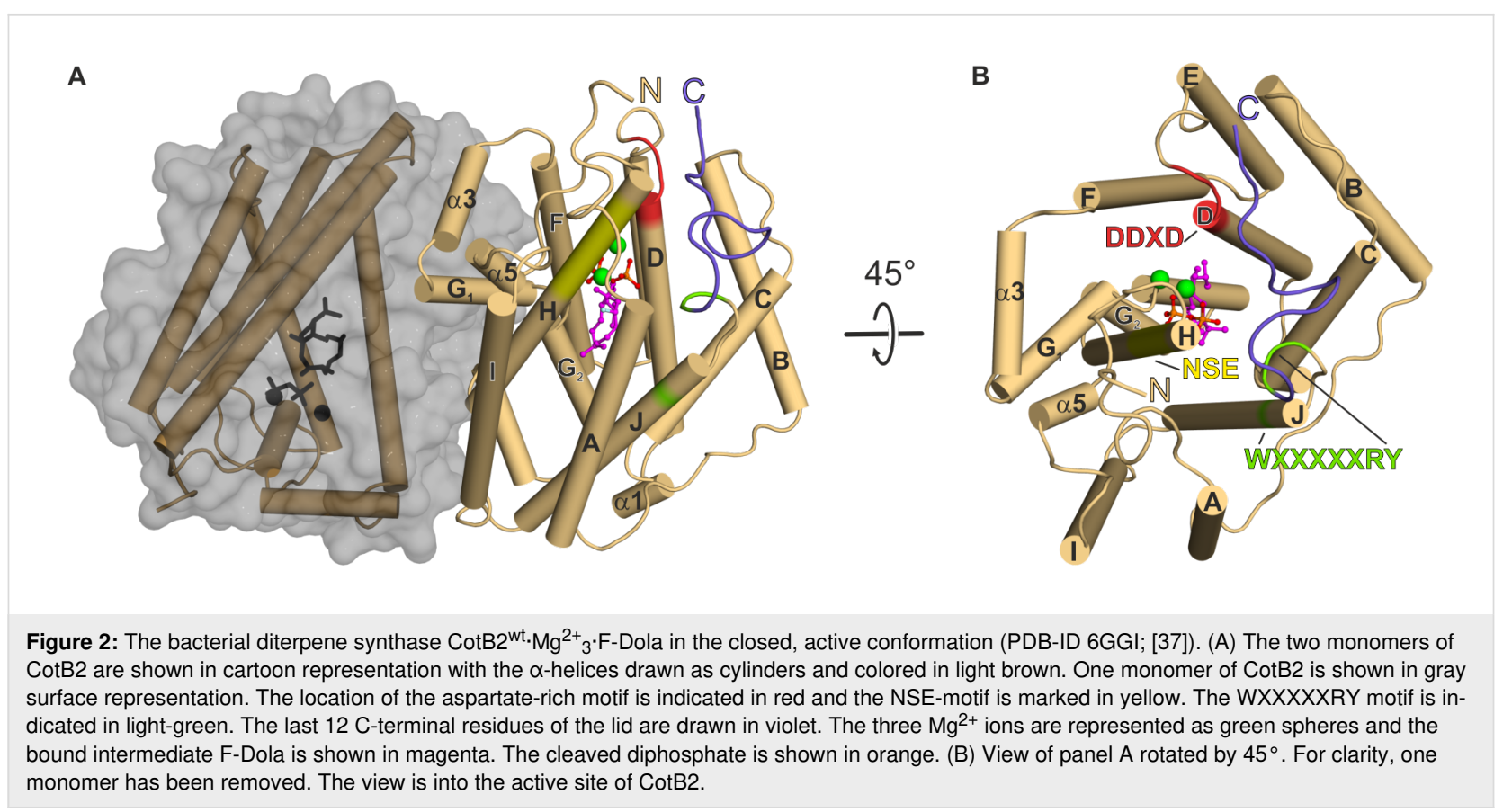

forms the active site (Figure 2A and B). CotB2 is arranged as a homo-dimer in crystallo $[36,38]$ and it was demonstrated that CotB2 exists as a homo-dimer in solution as well [38]. The two active sites of CotB2 are arranged in an antiparallel fashion, resembling the arrangement initially observed for the monoterpene (+)-bornyl diphosphate synthase [47] and the sesquiterpene trichodiene synthase [48], but is in contrast to the parallel dimer as described for farnesyl diphosphate synthase [49]. Structurally, CotB2 is most closely related to the fungal monoterpene synthase aristolochene (PDB-ID 2OA6; [50]), and epi-isozizaene synthase (PDB-ID 3LGK; [51]), but not to the known plant structures of diterpene TPSs, such as the entcopalyl diphosphate synthase (PDB-ID 3PYA; [52]) or taxadiene synthase (PDB-ID 3P5R; [53]).

\section{Two crystal structures of CotB2 resembling two distinct precatalytic states}

The structure of $\operatorname{CotB} 2^{\text {F107A }}$ was determined with one single $\mathrm{Mg}^{2+}\left(\mathrm{Mg}^{2+}{ }_{\mathrm{B}}\right)$ bound to the NSE motif $\left(\mathrm{CotB} 2^{\mathrm{F} 107 \mathrm{~A}} \cdot \mathrm{Mg}^{2+}{ }_{\mathrm{B}}\right.$; PDB-ID 6GGL [37]). The overall structure of CotB2 remains unchanged compared to the open state. This suggests that binding of $\mathrm{Mg}^{2+}{ }_{\mathrm{B}}$ is the initial step to prearrange CotB2 for substrate binding.

Tomita et al. obtained a crystal structure of $\operatorname{CotB} 2{ }^{\mathrm{wt}}$ with bound inert substrate analogue geranylgeranyl thiodiphosphate (GGSDP; CotB2 ${ }^{\mathrm{wt}} \cdot \mathrm{Mg}^{2+}{ }_{\mathrm{B}} \cdot \mathrm{GGSDP}$; PDB-ID 5GUE; [36]), resembling the next precatalytic state of CotB2. Surprisingly, there is only $\mathrm{Mg}^{2+}{ }_{\mathrm{B}}$ bound to the enzyme and not the full set of three $\mathrm{Mg}^{2+}$-ions needed for catalysis. The position of $\mathrm{Mg}^{2+}{ }_{\mathrm{B}}$ is identical to the structure of $\operatorname{CotB} 2^{\mathrm{F} 107 \mathrm{~A}} \cdot \mathrm{Mg}^{2+}{ }_{\mathrm{B}}$, but two coordinating water molecules have now been exchanged with two oxygen atoms of the diphosphate function of GGSDP. Upon binding of GGSDP, a bidentate salt bridge between D111 of the DDXD motif and R294 of the WXXXXXRY motif is formed, designating the transition from the open to the closed conformation. However as for the open, inactive conformation, the remaining $\mathrm{C}$-terminal residues have not been traceable in the electron density (Figure 3), and hence CotB2 is not yet ready for catalysis. The position and tilting of the core $\alpha$-helices in the structure of CotB2 ${ }^{\mathrm{wt}} \cdot \mathrm{Mg}^{2+}{ }_{\mathrm{B}} \cdot \mathrm{GGSDP}$ is practically indistinguishable from the open conformation of CotB2 (Figure 3). Since in CotB2 ${ }^{\mathrm{wt}} \cdot \mathrm{Mg}^{2+}{ }_{\mathrm{B}}$. GGSDP two $\mathrm{Mg}^{2+}$ ions are absent the diphosphate moiety is not properly coordinated, resulting in significant substrate flexibility within the catalytically active site. Moreover, the two missing $\mathrm{Mg}^{2+}$ ions prevent helix $\mathrm{D}$, accommodating the Asp-rich motif, from shifting towards the active site (Figure 3). Consequently, the active site remains partially open and the C-terminus cannot fold over the active site, making a proper substrate positioning and subsequent cyclization unlikely.

\section{Crystal structure of CotB2 ${ }^{\mathrm{wt}} \cdot \mathrm{Mg}^{2+}{ }_{3} \cdot \mathrm{F}$-Dola resembles the closed, active conformation}

The structure of CotB2 ${ }^{\mathrm{wt}} \cdot \mathrm{Mg}^{2+}{ }_{3} \cdot \mathrm{F}$-Dola has been obtained by co-crystallization of CotB2 ${ }^{\mathrm{wt}}$ and FGGDP (PDB-ID 6GGI; [37]), representing the closed, active conformation. Fluorinated substrates, such as FGGDP, have been used for the crystallization of other TPSs and have been shown to stick to the active site without undergoing cyclization, trapping the enzyme in a 


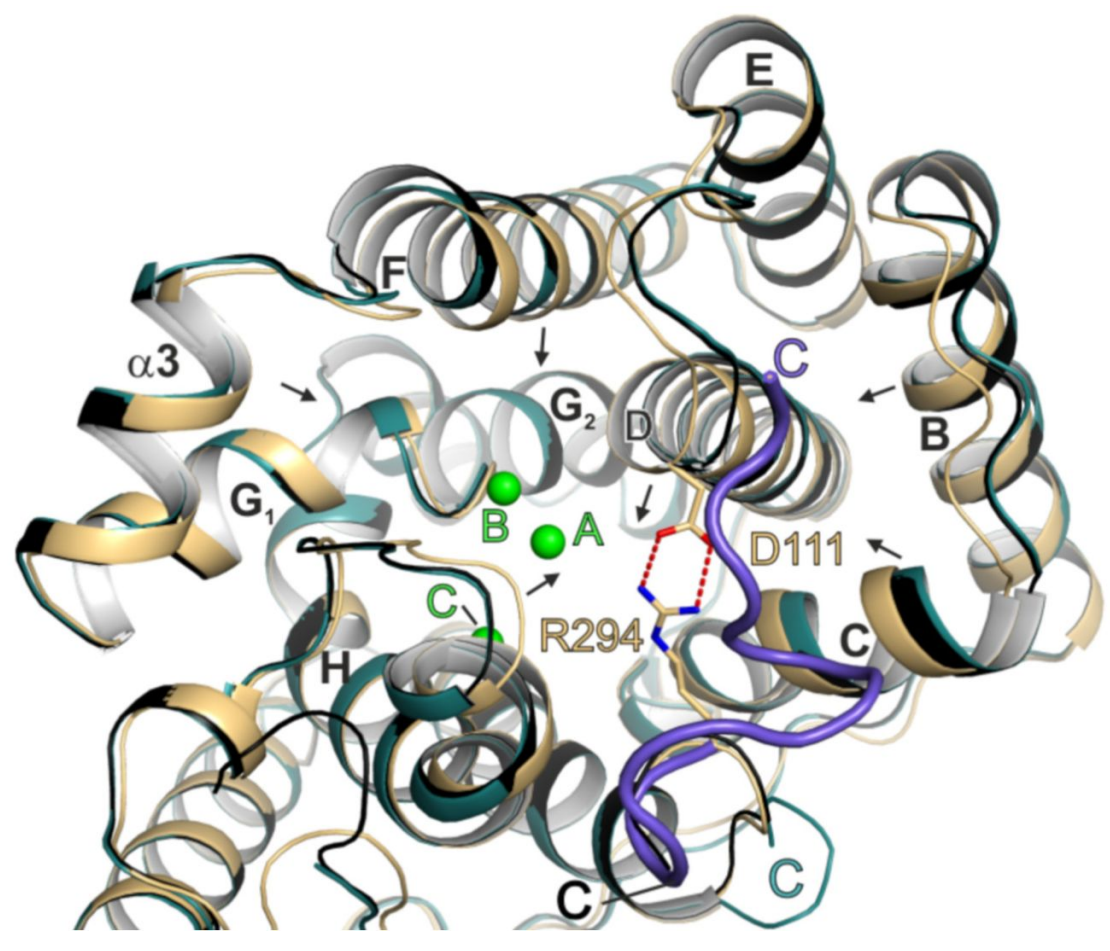

Figure 3: Conformational changes of CotB2 upon ligand binding. Superposition of CotB2's open (teal), pre-catalytic (black, CotB2wt.Mg $\left.{ }^{2+}{ }_{B} \cdot G G S D P\right)$, and fully closed (light-brown, CotB2 ${ }^{\text {wt. }} \cdot \mathrm{Mg}^{2+}{ }_{3}$. F-Dola) conformation. The overall fold of CotB2 ${ }^{\text {wt. }} \cdot \mathrm{Mg}^{2+}{ }_{B}$.GGSDP (PDB-ID 5GUE; [36]) is more similar to CotB2 $^{\text {wt }}$ (PDB-ID 4OMG; [38]) than to CotB2 ${ }^{\text {wt. }} \cdot \mathrm{Mg}^{2+}{ }_{3} \cdot$ F-Dola (PDB-ID 6GGI; [37]). The salt bridge between D111 and R294, in stick representation, is shown by red, dashed lines. $\mathrm{Mg}^{2+}$ ions are colored in green. Black arrows indicate movement of secondary structure elements from the open to the closed conformation of CotB2. The different $\mathrm{C}$-termini are labeled in all three structures. The $\mathrm{C}$-terminus in the structure of CotB2 ${ }^{\text {wt. }} \mathrm{Mg}^{2+}{ }_{3}{ }^{.} \mathrm{F}$-Dola is colored in purple.

closed state [52,53]. Comparing the overall structure of CotB2 ${ }^{\mathrm{wt}} \cdot \mathrm{Mg}^{2+}{ }_{3} \cdot \mathrm{F}-$ Dola to the open conformation of CotB2 reveals major differences. The binding of FGGDP and three $\mathrm{Mg}^{2+}$ ions induces a translation and rotation of $\alpha$-helices B, C, $\mathrm{D}, \mathrm{F}$ and $\mathrm{H}$ towards the active site to accurately position the Asp-rich motif and to subsequently transfer the active site into a product-shaped conformation (Figure 3). Now, a significant change in the $\mathrm{C}$-terminal region of the enzyme is observed as the former unstructured C-terminus becomes folded, thereby acting as a lid to shield the active site from bulk solvent (Figure 2). To exclude that the folded C-terminus is due to crystal contacts and hence a crystallographic artifact, CotB2 was co-crystallized with AHD, a compound that mimics the diphosphate group of GGDP and acts as a suicide inhibitor. The crystal structure of CotB2 ${ }^{\mathrm{wt}} \cdot \mathrm{Mg}^{2+}{ }_{3}$. AHD (PDB-ID 6GGJ; [37]) confirmed the active site architecture as observed in the structure of $\operatorname{CotB} 2^{\mathrm{wt}} \cdot \mathrm{Mg}^{2+}{ }_{3} \cdot$ F-Dola and more importantly, that the folding of the $\mathrm{C}$-terminus is not a crystallographic artifact. To demonstrate the significance of the $\mathrm{C}$-terminus, a CotB2 truncation $\left(\operatorname{CotB} 2^{\Delta C}\right.$ ) was designed terminating at R294, thereby missing the $12 \mathrm{C}$-terminal residues, that correspond to the lid [37]. In activity experiments, no substrate conversion by
$\operatorname{CotB} 2^{\Delta C}$ was observed, stressing the fact, that the salt bridge D111-R294 is insufficient for catalysis. Instead, the full $\mathrm{C}$-terminus is required for catalysis.

In CotB2 ${ }^{\mathrm{wt}} \cdot \mathrm{Mg}^{2+}{ }_{3} \cdot \mathrm{F}$-Dola, there is no electron density observed for the intact FGGDP molecule. Instead two distinct and clearly separated electron densities are visible that could be readily interpreted as the reaction intermediate F-Dola, as well as a single diphosphate moiety. The FGGDP molecule - functionalized with a fluorine atom at the $\mathrm{C} 2$ position of its isoprenoid unit - can interfere with the propagation of the generated carbocation(s). Such cyclization reactions of fluorinated substrates have been reported previously [54,55]. However, the structure of CotB2 ${ }^{\mathrm{wt}} \cdot \mathrm{Mg}^{2+}{ }_{3} \cdot \mathrm{F}$-Dola represents the first reported structure of a TPS with an in crystallo formed and bound reaction product, together with the cleaved-off diphosphate. This is in contrast to the structure of taxadiene synthase (PDB-ID 3P5R; [53]), co-crystallized with FGGDP, where the substrate is bound but the cyclization reaction has not been initialized and consequently the substrate is not yet cleaved. Identical observations have been made for the crystal structure of aristolochene synthase co-crystallized with 2-fluoro diphos- 
phate (PDB-ID 3BNY; [56]). A structural comparison of CotB2 ${ }^{\mathrm{wt}} \cdot \mathrm{Mg}^{2+}{ }_{3} \cdot \mathrm{F}$-Dola and CotB2 ${ }^{\mathrm{wt}} \cdot \mathrm{Mg}^{2+}{ }_{\mathrm{B}} \cdot$ GGSDP reveals that the hydrophobic tail of GGSDP adopts a position similar to the cyclized intermediate in our $\operatorname{CotB} 2^{\mathrm{wt}} \cdot \mathrm{Mg}^{2+}{ }_{3}$. F-Dola structure (Figure 4), likely reflecting the already product-shaped architecture of the active site.

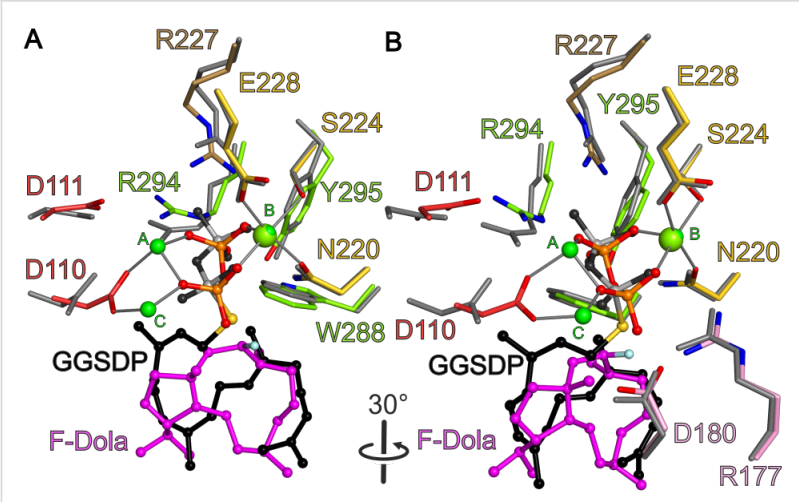

Figure 4: View into the active site of CotB2wt. $\mathrm{Mg}^{2+}{ }_{3} \cdot \mathrm{F}$-Dola [37] superimposed with CotB2 ${ }^{\text {wt. }} \mathrm{Mg}^{2+}{ }_{B} \cdot G G S D P$ [36]. (A) The bound F-Dola reaction intermediate is shown in magenta with the fluorine atom colored in light blue, and $\mathrm{Mg}^{2+}$ ions are shown in green. Residues of the DDXD motif are shown in red and residues of the NSE motif in yellow. The conserved residues of the WXXXXXRY motif are drawn in light green and the R227 that interacts with diphosphate moiety in light brown. The cleaved diphosphate is shown in orange. Gray lines represent the coordination sphere of the $\mathrm{Mg}^{2+}$ ions. Identical amino acid residues located in the structure of CotB2 ${ }^{\mathrm{wt}} \cdot \mathrm{Mg}^{2+}{ }_{B}$. GGSDP are shown in gray. The GGSDP molecule is shown in black with the sulfur atom colored in yellow. The position of $\mathrm{Mg}^{2+}{ }_{B}$ is identical in both structures. For clarity water molecules have been omitted. (B) View in panel $A$ rotated by $30^{\circ}$. In addition to the motifs shown in panel $A$, the pyrophosphate sensor motif is depicted in pink.

\section{Catalytic motifs of CotB2 $\mathrm{Mg}^{2+}$ coordination by the aspartate-rich and NSE motif}

Instead of the classical DDxxD motif for class I TPS, CotB2 contains a modified ${ }^{110} \mathrm{DDxD}{ }^{113}$ motif, which is neither characteristic for class I nor class II terpene synthases. In the literature, other TPSs with modified aspartate-rich motifs have been reported, encompassing selina-3,7(11)-diene synthase: ${ }^{82} \mathrm{DDGYCE}^{87}$ [57] and (+)-T-muurolol synthase: ${ }^{83} \mathrm{DDEYCD}^{88}$ [58]. It is commonly observed that the aspartaterich motif resides at the lower part of $\alpha$-helix D in the structure of class I TPSs. Interestingly, in $\operatorname{CotB} 2, \alpha$-helix D is rather short as a proline residue, adjacent to the third aspartate of the aspartate-rich motif, introduces a kink. In the closed conformation D110 is directly involved in the coordination of $\mathrm{Mg}^{2+} \mathrm{A}$ and $\mathrm{Mg}^{2+} \mathrm{C}$, whereas D111 forms a salt bridge with R294 (Figure 5). A third $\mathrm{Mg}^{2+}\left(\mathrm{Mg}^{2+}{ }_{\mathrm{B}}\right)$ is bound by the residues N220, S224 and E228 of the NSE motif [59], that is located on $\alpha$-helix E of CotB2 (Figure 5). D113 is surface exposed and points away from the active site and hence is likely not be involved in catal-

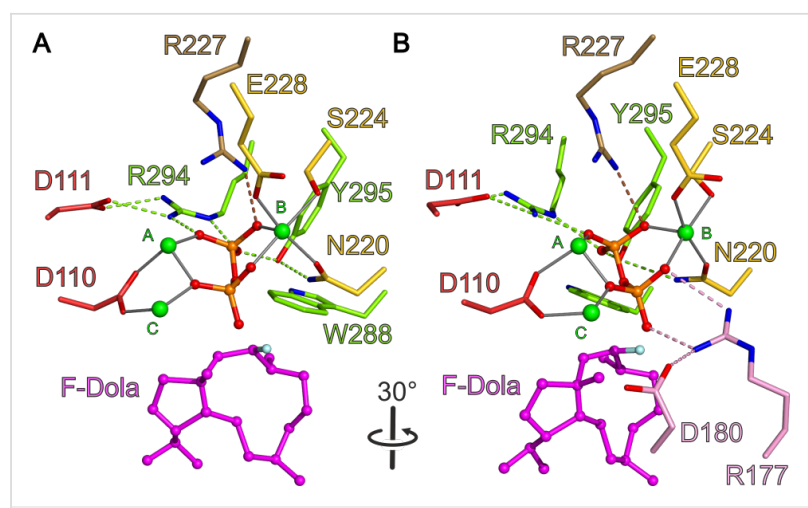

Figure 5: View into the active site of CotB2wt. $\mathrm{Mg}^{2+}{ }_{3} \cdot \mathrm{F}$-Dola [37]. Identical view as in Figure 4. (A) The bound F-Dola reaction intermediate is shown in magenta with the fluorine atom colored in light blue, and $\mathrm{Mg}^{2+}$-ions are shown in green. Residues of the DDXD motif are shown in red and residues of the NSE motif in yellow. The conserved residues of the WXXXXXRY motif are drawn in light green and the R227 that interacts with diphosphate moiety in light brown. The cleaved diphosphate is shown in orange. Hydrogen bonds and salt bridges are indicated by dashed lines in the same color-coding as the involved motifs. Gray lines represent the coordination sphere of the $\mathrm{Mg}^{2+}$-ions. For clarity water molecules have been omitted. (B) View in panel A rotated by $30^{\circ}$. In addition to the motifs shown in panel $A$, the pyrophosphate sensor motif is depicted in pink.

ysis. Latter structural findings are supported by site-directed mutagenesis studies [36,38], which showed that, whereas D110 and D111 are crucial for catalysis, the solvent exposed D113 is not. The here described structural situation is different compared to TPSs with a canonical DDXXD motif. For instance in the structure of epi-isozizaene synthase in complex with diphosphate, $3 \mathrm{Mg}^{2+}$ ions and $N$-benzyl- $N, N$-diethylethanaminium [51], the $\alpha$-helix is longer. Compared to $\operatorname{CotB} 2$, the first aspartate is as well involved in the coordination of $\mathrm{Mg}^{2+} \mathrm{A}$ and $\mathrm{Mg}^{2+} \mathrm{C}$ and the second aspartate forms a salt bridge with the $\mathrm{RY}$-pair, but the third aspartate is involved in coordination of water molecules in the water network around the catalytic $\mathrm{Mg}^{2+}$ ions.

\section{The pyrophosphate sensor motif}

In a recent review, the presence of a "pyrophosphate sensor", an arginine 46 amino acid residues upstream of the NSE motif, was discussed as a universal feature of bacterial TPSs [11]. Structural information on selina-4(15),7(11)-diene synthase (SdS), revealed that upon substrate binding by an induced fit mechanism, R178 changes its side chain conformation thereby approaching and interacting with the diphosphate function of the substrate analogue and forming a salt bridge to the neighboring D181 [60]. Moreover, a conformational change of the kink of the $\alpha$-helix G1 moves the catalytically important G182 (effector) towards the active site. Initiated by this induced fit mechanism, the active site is being closed and the Michaelis complex is formed. In CotB2, R177 represents the pyrophosphate sensor (Figure 5B) establishing identical interactions to 
the diphosphate moiety of the substrate and to D180. In contrast to $\mathrm{SdS}$, in CotB2 an additional residue is inserted between D180 and the effector G182. A comparison of the open and closed conformation of SdS revealed a large conformation change of the G1/G2 helix kink, which is not observed in the structures of CotB2 [36-38]. This might be explained by the observation that the pyrophosphate sensor of CotB2 R177 and D180 is already involved in a salt bridge in the open conformation.

\section{The WXXXXXRY motif}

Analyzing protein sequences of other bacterial TPSs for the presence of the RY pair, also called "basic pair" [61,62] and their flanking regions, led to the identification of a conserved tryptophan six amino acids upstream of the RY pair (Figure 6) [37]. In CotB2, residues of the motif are located at the end of the C-terminal core $\alpha$-helix J. The RY pair is a conserved feature among most bacterial and several types of fungal TPSs [62]. It is not only important for active site closure by establishing a salt bridge, but moreover for interaction with the substrate. In the closed conformation of CotB2, R294 is involved in a bidentate salt bridge with D111 of the aspartate-rich motif, and two salt bridges to the diphosphate moiety derived from FGGDP (Figure 3 and Figure 5). Y295 establishes hydrogen bonds to the diphosphate moiety as well as to N220 of the NSE motif (Figure 5). In the closed conformation of the labdanerelated diterpene synthase [63] the WXXXXXRY motif is present as well and adopts a nearly identical conformation as observed in the closed conformation of CotB2 ${ }^{\mathrm{wt}} \cdot \mathrm{Mg}^{2+}{ }_{3}$. F-Dola (PDB-ID 6GGI; [37]). Hence, the WXXXXXRY motif seems to be conserved not only sequence-based (Figure 6) but also structurally in other diterpene synthases. Hence, the discovery of this novel motif might help in the identification and functional assignment of novel TPSs.

The importance of the tryptophan residue in the WXXXXXRY motif of CotB2 was proven by mutation to glycine (W288G), where the product was changed to 3,7,18-dolabellatriene (12) [38]. If a less drastic mutation was introduced (W288F), preserving the aromatic character of the side chain, the product was not changed but the activity of CotB2 was reduced [37]. In other TPSs, a similar observation was made. Mutation of the corresponding residue $\mathrm{W} 308 \mathrm{~F}$ in the bacterial sesquiterpene synthase pentalenene synthase leads to a product mixture [64], whereas mutation of W273 in the plant-derived epi-aristolochene synthase resulted in total loss of enzymatic function [65]. Consequently, the aromatic character of the side chain in the WXXXXXRY motif is important for the propagation of the carbocation.

\section{Mechanistic aspects of the cyclization reaction and point mutations}

The floor of the active site is decorated by hydrophobic residues V80, F107, W109, F149, V150, I181, F185, M189, W186, L281, and W288 conferring the overall shape to the cavity that serves as a template for the binding of GGDP and the cyclization reaction. Based on ${ }^{2} \mathrm{H}$ - as well as ${ }^{13} \mathrm{C}$-isotope labeling experiments a surprising reaction mechanism has been derived (Scheme 2) [35]. Strong support for the proposed reaction mechanism has been predominantly provided by site-directed mutagenesis of amino acids with an aromatic function [30,3638] (Table 2 and Scheme 1), which significantly affect the product profile.

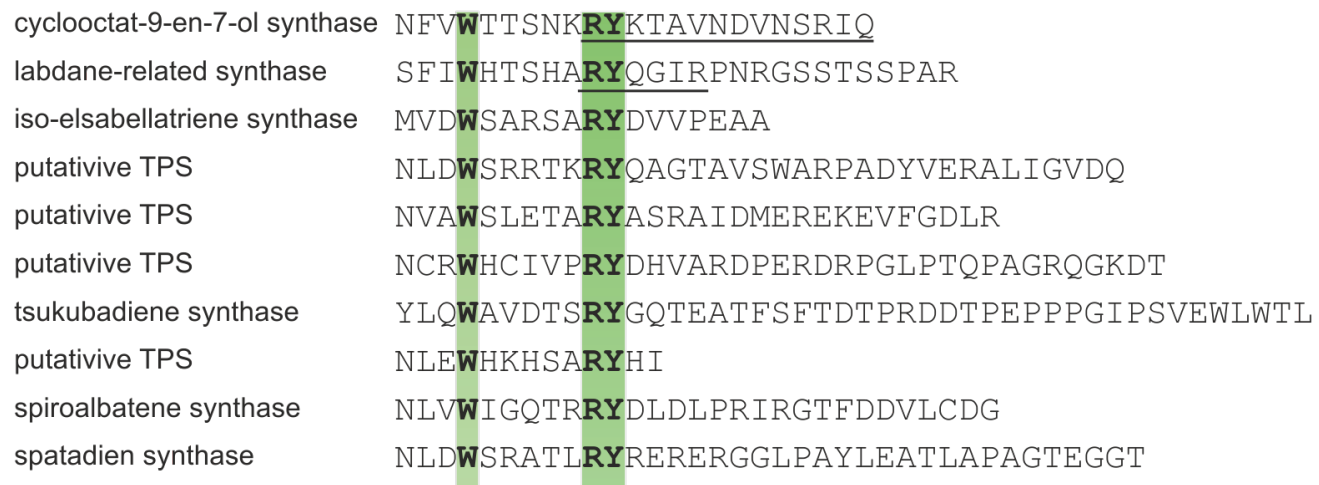

Figure 6: The WXXXXXRY motif in protein sequences of diterpene TPS from different bacteria. Highlighted is the WXXXXXRY motif in green. Underlined sequences refer to crystal structures of the respective diterpene TPS in the closed conformation, with a structured C-terminus. Cyclooctat-9-en7-ol synthase (WP_093468823), S. melanosporofaciens; labdane-related diterpene synthase (WP_019525557), Streptomyces K155; iso-elsabellatriene synthase (WP_003963279), Streptomyces clavuligerus; terpene synthase (WP_046708564.1), Streptomyces europaeiscabiei; terpene synthase (WP_012394883), Myobacterium marinum; diterpene synthase (BAP82229), Streptomyces sp. ND90; tsukubadiene synthase (EIF90392), Streptomyces tsukubaensis NRRL 18488; terpene synthase (ZP_00085244), Pseudomonas fluorescens PfO-1; spiroalbatene synthase (WP_030426588.1), Allokutzneria albata; spatadien synthase (WP_095757924.1) Streptomyces xinghaiensis. 
Table 2: CotB2 and its variants as well as the altered products.

\begin{tabular}{|c|c|c|}
\hline variant & product & reference \\
\hline wild-type & cyclooctat-9-en-7-ol (4) & {$[31]$} \\
\hline N103A & 3,7,12-dolabellatriene (6) & {$[36]$} \\
\hline F107A & $R$-cembrene A (7) & {$[30]$} \\
\hline F107Y & cyclooctat-1,7-diene (8) & [30] \\
\hline F107L & $\begin{array}{l}\text { cyclooctat-9-en-7-ol (4) } \\
\text { 3,7-dolabelladiene-9-ol (9) } \\
\text { cyclooctat-6-en-8-ol (10) }\end{array}$ & {$[30,36]$} \\
\hline F149L & cyclooctat-7-en-3-ol (11) & {$[30]$} \\
\hline F185A & $\begin{array}{l}\text { cyclooctat-9-en-7-ol (4) } \\
\text { cyclooctat-6-en-8-ol (10) }\end{array}$ & {$[36]$} \\
\hline W186L & $\begin{array}{l}\text { cyclooctat-9-en-7-ol (4) } \\
\text { cembrane A (7) } \\
\text { 3,7,18-dolabellatriene (12) }\end{array}$ & {$[36]$} \\
\hline W186F & $\begin{array}{l}\text { cyclooctat-9-en-7-ol (4) } \\
\text { cyclooctat-7-en-3-ol (11) } \\
\text { 3,7-dolabelladiene-9-ol (9) } \\
\text { cyclooctat-6-en-8-ol (10) }\end{array}$ & {$[36]$} \\
\hline W186H & $\begin{array}{l}\text { cyclooctat-7-en-3-ol (11) } \\
\text { 3,7,18-dolabellatriene (12) }\end{array}$ & {$[36,38]$} \\
\hline W288G & 3,7,18-dolabellatriene (12) & [38] \\
\hline
\end{tabular}

Further support for the reaction mechanism was generated by gas-phase calculations [33,34] as well as in silico multiscale modeling [37], which suggest an active role of the enzyme during catalysis.

Cyclization is initiated by cleavage of the GGDP diphosphate moiety. After two consecutive cyclization reactions, a dolabellatrienyl cation (A) is generated, stabilized by $\pi$-cation interactions with W186 (Scheme 2 and Figure 7). Whereas mutation of this residue to amino acids with aromatic character mainly lead to different migration of the double bound and different hydroxylation pattern (Table 2 and Scheme 1). An exchange to leucine drastically changes the product to cembrane A (7) and 3,7,18-dolabellatriene 12 (Table 2 and Scheme 1) [36]. The cation migrates via a 1,5 hydride shift, as shown by deuterium labeling [33-35], to form the carbocation located at position $\mathrm{C} 8$ of dolabellatrienyl (B). By ring closure and formation of a novel $\mathrm{C}-\mathrm{C}$ bond the tricyclic 5-8-5 ring system $(\mathbf{C})$ is established. F107, F149, and the pyrophosphate moiety stabilize the carbocation at position C3 (Scheme 2 and Figure 7). F107 has been targeted by site-directed mutagenesis as well (Table 2 and Scheme 1) [30], leading to compounds $R$-cembrene A (7) and cyclooctat-1,7-diene (8). Now the cationic intermediate has two possibilities to react to $\mathbf{G}$, either by a 1,3- and 1,5-hydride shift or by two 1,2-hydride shifts followed by a 1,5-hydride shift. The sequential 1,2-hydride shift ( $\mathbf{C}$ to $\mathbf{E}$ ) route was initially suggested by theoretical calculations, which supported the overall mechanism [33,34], and this was verified via isotope labeling [34]. Such series of two 1,2-hydride shifts have previously been demonstrated experimentally for tsukubadiene synthase [66]. Compound E is stabilized by F107 (Scheme 2 and Figure 7) and the backbone carbonyl of I181. Compound $\mathbf{G}$ is obtained by another 1,5-hydride shift as proven by isotope labeling [35]. The carbocation located at $\mathrm{C} 10$ is stabilized by N103 and T106. A mutation of N103 to alanine, bearing the possibility to stabilize the carbocation, results in 3,7,12-dolabellatriene 6 (Table 2 and Scheme 1). Finally, the cyclopropyl ring is opened by a 1,3-alkyl shift and a subsequent nucleophilic attack by a water molecule at $\mathrm{C} 7$ yields the product cycloocat9-en-7-ol (4). Notably, no water has been observed in the structural investigations that could resume the nucleophilic attack.

\section{Biotechnological applications to exploit the chemistry of CotB2}

The mutants described in Table 2 are not only important for resolving structure-function relationships, they also convey the<smiles>CC(C)C1CC[C@]2(C)C[C@H]3[C@@H](C)CC[C@H]3[C@](C)(O)C/C=C/12</smiles>

4

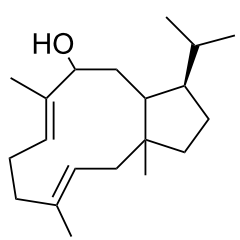

9<smiles>CC(C)=CCC1(C)CC=C2C(C)=CCCC(C(C)C)C2CC1</smiles>

6<smiles>C/C1=C2\CCC(C)C2CC2(C)CCC(C(C)C)C2CC1O</smiles>

10

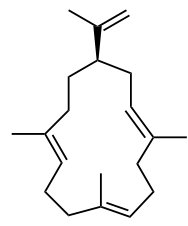

7

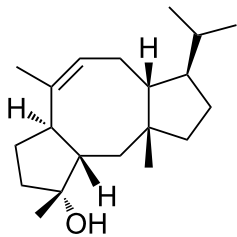

11<smiles>C/C1=C/CC2C(C(C)C)CC[C@]2(C)/C=C2/C(C)CC[C@H]12</smiles>

8

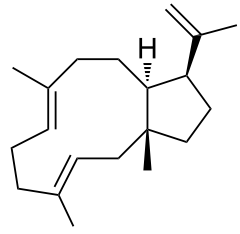

12

Scheme 1: Overview of the altered product portfolio as a result of introduced point mutations in the active site of CotB2. For an overview of the point mutations see Table 2. 


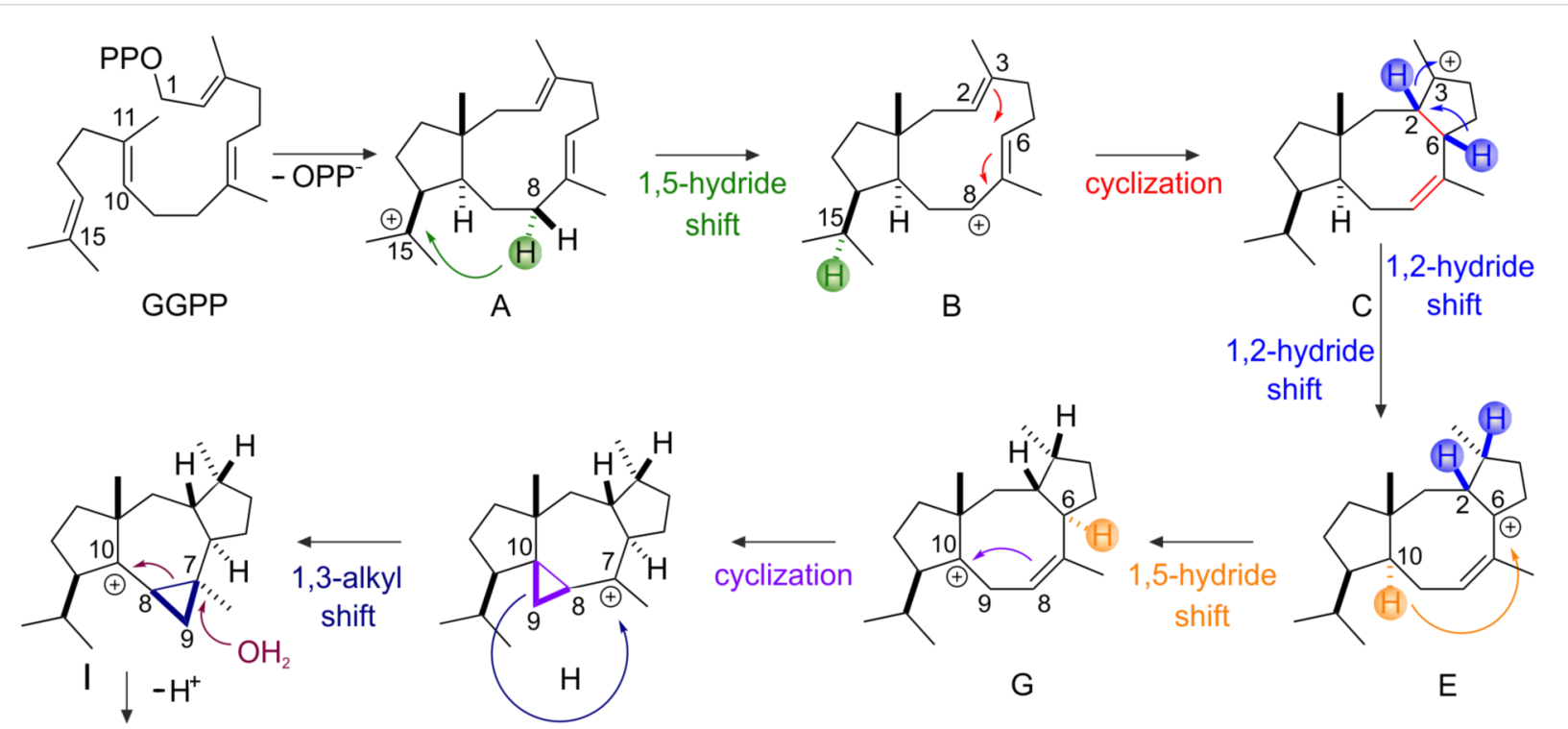

cyclooctat-9-en-7-ol 4

Scheme 2: Catalytic mechanism of CotB2, derived from isotope labeling experiments [34,35], density functional theory calculations [33] as well as QM/MM simulations [37].


Figure 7: (A) The inner surface of the active site is shown in gray. The bound F-Dola reaction intermediate is shown in magenta with the fluorine atom colored in light blue. Aromatic residues are shown in black stick representation (B) View of panel A rotated by $90^{\circ}$. (C) View from the top into the active site of CotB2. View of panel A rotated by $90^{\circ}$.

conversion to carbon skeletons of other bioactive natural product classes. In light of this fact, the exchange of only one amino acid changes the product portfolio from cyclooctatin (5) belonging to the fusicoccane diterpene family to compounds of the dolabellane [67] or the cembranoid class [68].

The dolabellane diterpenes synthesized by the respective synthase mutants are missing the bond between $\mathrm{C} 2$ and $\mathrm{C} 6$ compared to cyclooctatin (5). Hence, they are comprising a 5,11-fused bicyclic skeleton. In contrast, cembranoids are monocyclic compounds consisting of a 14 membered ring structure. Common to all compounds available via the CotB2 mutants is the necessity of further decoration with functional groups, like hydroxylations or epoxidations, to induce the desired bioactivity (Scheme 3). Modification descriptions in the next chapters are composed according to the atom numbering in (Scheme 3). Lead structure for the dolabellane derivatives is 3,7,18-dolabellatriene (12) and cembrene A (7) for the cembranoid family, respectively (Scheme 3).

Dolabellanes comprise a diverse group of bioactive diterpenes, with the first compounds initially isolated from the mollusc Dolabella californica in 1977 [69]. Later, the product family was widened by molecules isolated from other marine organisms, like sponges, sea whips and the brown algae of this genus Dictyota [70]. Two modifications would transform 3,7,18-dolabellatriene (12, Scheme 3$)$ into a potent cytotoxic molecule with activity towards murine leukemia cells or human non-small cell 


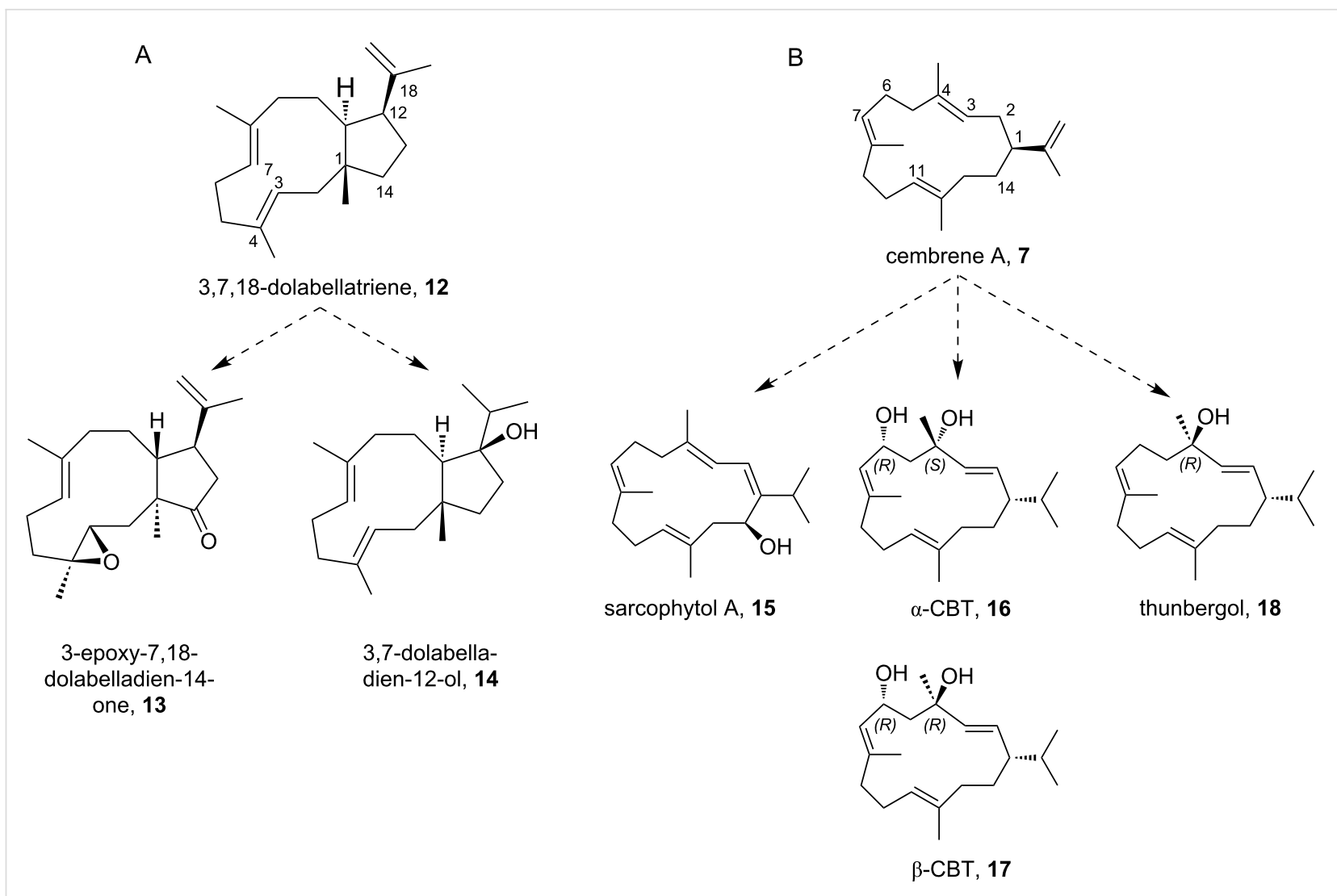

Scheme 3: Variants of CotB2 open the route to a novel product portfolio with altered cyclic carbon skeletons, which can be converted into bioactive compounds by chemo-enzymatic methodologies. Modification descriptions are composed according to the atom numbering. (A) Lead structure for the dolabellane derivatives is 3,7,18-dolabellatriene (12) and (B) cembrene A (7) for the cembranoid family.

lung cancer with $\mathrm{ED}_{50}$ values of 6.5 and $16.7 \mu \mathrm{g} \mathrm{mL}^{-1}$, respectively [71]. To obtain this interesting compound isolated from Dictyota dichotoma, $\mathrm{C} 14$ has to be modified with a keto function and the double bond between $\mathrm{C} 3$ and $\mathrm{C} 4$ has to be converted into an epoxide. Additionally, 3,7,18-dolabellatriene (12) possesses a mainly weak antibiotic activity against different types of Staphylococcus aureus strains (two epidemic MRSA strains, a macrolide-resistant variant and two multidrug-resistant efluxing strains) [72]. By contrast, 3,7,18-dolabellatriene (12, Scheme 3), only altered at C14 with a hydroxy group, showed a significant increase in potency (compound 14). Here the MIC values were as low as $4 \mu \mathrm{g} \mathrm{mL}^{-1}$ for a macrolide-resistant and one multidrug-resistant effluxing variant, as well as $2 \mu \mathrm{g} \mathrm{mL}^{-1}$ for two epidemic MRSA and another multidrugresistant effluxing strain.

The first bioactive molecule of the cembranoid family sarcophytol A (15), isolated in 1979 from the soft coral Sarcophyton glaucum [73], is structurally closely related to $R$-cembrene A (7, Scheme 3). In order to obtain sarcophytol A (15), two reactions have to be applied to compound 7: First a base induced double bond shift to gain cembrene $\mathrm{C}$ and second a hydroxylation at C14. Sarcophytol A (15), is a promising target as it possesses inhibitory activity against potent tumor promotors, like teleocidin [74]. Interestingly, sarcophytol A (15) was already inhibitory at equimolar amounts in contrast to other natural antitumor promotors, like flavonoids or dihydroxycembranoids from tobacco leaves, which has to be applied at a factor of thousand or more compared to the promotor quantity to be reasonably active. Moreover, sarcophytol A (15) inhibits the expression of the tumor necrosis factor- $\alpha$ (TNF- $\alpha$ ) mRNA and the release of TNF- $\alpha$ by BALB/3T3 cells [75]. This cancer prevention activity can be initiated at an $\mathrm{IC}_{50}$ of only $2.5 \mu \mathrm{M}$.

Other bioactive target molecules structurally accessible from compound 7 could be both epimers of (6R)-2,7,11-cembratriene-4,6-diol either 4S: $\alpha$-CBT 16 or $4 \mathrm{R}: \beta$-CBT 17 (Scheme 3). Both were isolated in 1985 from cigarette smoke condensate and identified as anticancer agents [76]. With quite similar potency ( $\alpha$-CBT: $25.2 \mu \mathrm{M}$ and $\beta$-CBT: $21.9 \mu \mathrm{M}$ [77]), they showed inhibition of the induction of Epstein-Barr virus early antigen by lymphoblastoid cancer cells. In the tobacco plant itself, both substances, in addition to being key flavor 
ingredients [78], play a major role in the defence against insects, pathogenic microbes and herbivores [79]. Furthermore, $\beta$-CBT 17 showed additional antibiotic activity against multidrug resistant $S$. aureus strains, [80], as well as neuroprotective activity [81].

Interestingly, the $\beta$-CBT derivative missing the hydroxy group at $\mathrm{C} 6$ called thunbergol (18, Scheme 3), already inhibited the growth of two parasites Trypanosoma brucei rhodesiense, causing African sleeping sickness, as well as Plasmodium falciparum causing Malaria tropica, while having only minor human cytotoxicity [82]. Further, thunbergol (18) is reported to repel aphids within $48 \mathrm{~h}$ by $70 \%$, if wheat seedlings are topically treated with a $0.25 \%(\mathrm{w} / \mathrm{w})$ solution in ethyl acetate, compared to untreated plants [25]. During application in agriculture a negative impact on useful insects, like bees, should be avoided. A hint in this direction could be that in an in vitro experiment with Spodoptera frugiperda insect cells, a high resilience could be detected with an $\mathrm{IC}_{50}$ of $68 \mu \mathrm{M}$. Furthermore, Gram-positive bacteria are significantly growth inhibited through thunbergol (18) exposure with an $\mathrm{IC}_{50}$ for Bacillus subtilis of $9 \mu \mathrm{M}$ and $10 \mu \mathrm{M}$ for Micrococcus luteus, respectively [25].

For the sustainable, high yield production of bioactive diterpenoids various aspects have to be considered. One key issue in yielding high recombinant terpene production titers, are metabolic bottlenecks in the precursor supply, which have to be circumvented [83]. In that regard, there are different ways of enhancing E. coli host productivity. First, the general production pathway is usually genetically established. Choosing a plasmid-based production pathway has the advantage, that single genes can be exchanged or added quite rapidly [84]. Furthermore, decreasing the metabolic burden of the plasmid construct on the native host metabolism [85] can be achieved by using polycistronic operons to reduce the amount of plasmid in a cell. Additionally, computer aided fine-tuning [86] of transcription rates by promotor [24] and RBS [87] variations will further enhance the production rate [25]. Alternatively, permanent integration of the heterologous genes into the host genome is an alternative strategy to circumvent metabolic stress by antibiotics, which are required to maintain a plasmid in the production host [28]. Nevertheless, genomic integration procedures into the E. coli genome are time-consuming and have the disadvantage of having only a single copy in the host genome. Thus, expression and subsequently production rates of a previously optimized plasmid based system are not transferable to a genomically integrated system. In that respect, each operon has to be optimized de novo, whereby also the loci of integration have a severe impact on the expression rates of genome integrated heterologous gene material [88-90].

\section{Perspectives}

CotB2 is an exciting example of how nature evolved an enzyme to perform very sophisticated chemistry. Mechanistically, CotB2 is very well understood, based on data from various different disciplines [30,31,33,35-38]. TPSs play an active role in all steps from the initialization of the diphosphate cleavage, and end with the nucleophilic attack of a water molecule. Yet, there is a dogmatic dispute in the TPS community about the respective roles of the protein acting as a scaffold and the "inherent" carbocation reactivity [91] in orchestrating an enzyme specific reaction cascade. With regard to the latter, the "inherent reactivity" of carbocations is no doubt an important ingredient in terpene biosynthesis. The enzyme could be understood as passive catalyst, essentially chaperoning the intermediates during the reaction cascade. It is clear that much of terpene biosynthesis can be understood by this concept. "Inherent reactivity" largely relies on theoretical calculations performed in the gas phase [92,93]. The latter approach per se disregards the role of the protein scaffold during catalysis. However, there are many examples of mono-, sesqui-, and diterpene synthases, where the contribution of the diphosphate and selected amino acid residues, which decorate the active site, on carbocation stability has been demonstrated [94-98]. These studies reveal a significant effect of individual active site moieties on TPS reactions in respect of product formation or alteration of the product profile. Additionally, numerous theoretical studies have emphasized the role of the enzyme environment in guiding the reaction cascade [94,99-102]. In case of CotB2, mutagenesis studies of plasticity residues of CotB2 [30,36-38] have been demonstrated to drastically change the propagation of the carbocations and consequently alter the product portfolio (Table 2 and Scheme 1).

Notably, in the crystal structures of CotB2 (Table 1) [36-38], we perceive that the amino acid side chains with an aromatic character in the active site (Figure 7) frequently adopt energetically unfavorable side chain conformations. Moreover, the crystal structures of the $\operatorname{CotB} 2^{\mathrm{F} 107 \mathrm{~A}}$ [37] and $\operatorname{CotB} 2^{\mathrm{F} 149 \mathrm{~L}}$ [38] variants revealed that other aromatic amino acid side chains adopt different side chain conformations compared to the structure of CotB2 ${ }^{\mathrm{wt}}$. This hints to long-range effects of the introduced mutation on other amino acid side chains in the active cavity. We are convinced that this plasticity of side chains in the active site of CotB2 plays not only an important role in stabilization and hence propagation of carbocations.

In future experiments, it would be interesting to investigate the influence of double or triple mutations within the active site. Moreover, it would be interesting to prepare a CotB2 variant with a canonical aspartate-rich motif and to study the influence on catalysis, whether the product portfolio is affected or not. 
Since until now no water molecule could be located in the electron density maps, in terms of catalysis the question remains which entity performs the nucleophilic attack at position $\mathrm{C} 7$ to give the final product cyclocotat-9-en-7-ol (12).

Another direction, to expand the chemical space, is the exploitation of TPSs to generate novel compounds that could be further functionalized by classical organic chemistry. Examples of this include epoxidation resulting in 3,4-epoxy-7,18-dolabelladien14-one (13) or hydroboration of 3,7,18-dolabellatriene (12 Scheme 1) that has been previously biotechnologically manufactured using CotB2 ${ }^{\mathrm{W} 288 \mathrm{G}}$ [103]. Another successful example is the oxidative transformation of cattleyene and phomopsen [104]. Yet another approach is the use of heteroatom-modified farnesyl diphosphates that could be still cyclized by TPSs yielding unnatural terpenoids [105].

\section{Acknowledgements}

R. Driller was supported by Elsa-Neumann and NüssleinVolhard stipends. D. T. Major acknowledges support from the Israel Science Foundation (Grant \#2146/15 and 1683/18). T. Brück gratefully acknowledges funding by the Werner Siemens foundation for establishing the field of Synthetic Biotechnology at the Technical University of Munich (TUM). Additionally, the German Federal Ministry of Education and Research supported TB and DG through the project OMCBP (Grant \#031A276A), while TB and MF were supported by the project SysBioTerp (Grant \#031A305A). Furthermore, TB and NM acknowledge funding by the Bavarian Ministry of Economic Affairs, Regional Development and Energy for the bioinsecticide project (Grant \#1340/68351/13/2013). We are grateful to $\mathrm{M}$. Wahl for continuous encouragement and support.

\section{ORCID ${ }^{\circledR}$ iDs}

Ronja Driller - https://orcid.org/0000-0001-8834-9087 Daniel Garbe - https://orcid.org/0000-0001-7203-8751 Monika Fuchs - https://orcid.org/0000-0002-6954-2639 Dan Thomas Major - https://orcid.org/0000-0002-9231-0676 Thomas Brück - https://orcid.org/0000-0002-2113-6957 Bernhard Loll - https://orcid.org/0000-0001-7928-4488

\section{References}

1. Christianson, D. W. Chem. Rev. 2006, 106, 3412-3442. doi:10.1021/cr050286w

2. Christianson, D. W. Science 2007, 316, 60-61. doi:10.1126/science. 1141630

3. Christianson, D. W. Chem. Rev. 2017, 117, 11570-11648. doi:10.1021/acs.chemrev.7b00287

4. Mayer, A. M. S.; Gustafson, K. R. Int. J. Cancer 2003, 105, 291-299. doi:10.1002/ijc.11080

5. Ebel, R. Mar. Drugs 2010, 8, 2340-2368. doi:10.3390/md8082340
6. Elissawy, A.; El-Shazly, M.; Ebada, S.; Singab, A.; Proksch, P. Mar. Drugs 2015, 13, 1966-1992. doi:10.3390/md13041966

7. Shirai, M.; Okuda, M.; Motohashi, K.; Imoto, M.; Furihata, K.; Matsuo, Y.; Katsuta, A.; Shizuri, Y.; Seto, H. J. Antibiot. 2010, 63, 245-250. doi:10.1038/ja.2010.30

8. Dickschat, J. S. Angew. Chem., Int. Ed. 2019, in press. doi:10.1002/anie.201905312

9. Brück, T.; Kourist, R.; Loll, B. ChemCatChem 2014, 6, 1142-1165. doi:10.1002/cctc.201300733

10. Newman, D. J.; Cragg, G. M. J. Nat. Prod. 2016, 79, 629-661. doi:10.1021/acs.jnatprod.5b01055

11. Dickschat, J. S. Nat. Prod. Rep. 2016, 33, 87-110. doi:10.1039/c5np00102a

12. Poulter, C. D.; Argyle, J. C.; Mash, E. A. J. Biol. Chem. 1978, 253, 7227-7233.

13. Maimone, T. J.; Baran, P. S. Nat. Chem. Biol. 2007, 3, 396-407. doi:10.1038/nchembio.2007.1

14. Christianson, D. W. Curr. Opin. Chem. Biol. 2008, 12, 141-150. doi:10.1016/j.cbpa.2007.12.008

15. Sacchettini, J. C.; Poulter, C. D. Science 1997, 277, 1788-1789. doi:10.1126/science.277.5333.1788

16. Cane, D. E. Chem. Rev. 1990, 90, 1089-1103. doi:10.1021/cr00105a002

17. Lesburg, C. A.; Caruthers, J. M.; Paschall, C. M.; Christianson, D. W. Curr. Opin. Struct. Biol. 1998, 8, 695-703. doi:10.1016/s0959-440x(98)80088-2

18. Wendt, K. U.; Schulz, G. E. Structure 1998, 6, 127-133. doi:10.1016/s0969-2126(98)00015-x

19. Hamano, Y.; Kuzuyama, T.; Itoh, N.; Furihata, K.; Seto, H.; Dairi, T. J. Biol. Chem. 2002, 277, 37098-37104. doi:10.1074/jbc.m206382200

20. Smanski, M. J.; Yu, Z.; Casper, J.; Lin, S.; Peterson, R. M.; Chen, Y.; Wendt-Pienkowski, E.; Rajski, S. R.; Shen, B.

Proc. Natl. Acad. Sci. U. S. A. 2011, 108, 13498-13503. doi:10.1073/pnas.1106919108

21. Chen, M.; Harris, G. G.; Pemberton, T. A.; Christianson, D. W. Curr. Opin. Struct. Biol. 2016, 41, 27-37. doi:10.1016/j.sbi.2016.05.010

22. Aaron, J. A.; Christianson, D. W. Pure Appl. Chem. 2010, 82, 1585-1597. doi:10.1351/pac-con-09-09-37

23. Smanski, M. J.; Peterson, R. M.; Huang, S.-X.; Shen, B. Curr. Opin. Chem. Biol. 2012, 16, 132-141. doi:10.1016/j.cbpa.2012.03.002

24. Hirte, M.; Mischko, W.; Kemper, K.; Röhrer, S.; Huber, C.; Fuchs, M.; Eisenreich, W.; Minceva, M.; Brück, T. B. Green Chem. 2018, 20 , 5374-5384. doi:10.1039/c8gc03126f

25. Mischko, W.; Hirte, M.; Roehrer, S.; Engelhardt, H.; Mehlmer, N.; Minceva, M.; Brück, T. Green Chem. 2018, 20, 2637-2650. doi:10.1039/c8gc00434j

26. Kemper, K.; Hirte, M.; Reinbold, M.; Fuchs, M.; Brück, T. Beilstein J. Org. Chem. 2017, 13, 845-854. doi:10.3762/bjoc.13.85

27. Hirte, M.; Meese, N.; Mertz, M.; Fuchs, M.; Brück, T. B. Front. Chem. (Lausanne, Switz.) 2018, 6, 101. doi:10.3389/fchem.2018.00101

28. Ajikumar, P. K.; Xiao, W.-H.; Tyo, K. E. J.; Wang, Y.; Simeon, F.; Leonard, E.; Mucha, O.; Phon, T. H.; Pfeifer, B.; Stephanopoulos, G. Science 2010, 330, 70-74. doi:10.1126/science.1191652

29. Anthony, J. R.; Anthony, L. C.; Nowroozi, F.; Kwon, G.; Newman, J. D.; Keasling, J. D. Metab. Eng. 2009, 11, 13-19. doi:10.1016/j.ymben.2008.07.007 
30. Görner, C.; Häuslein, I.; Schrepfer, P.; Eisenreich, W.; Brück, T. ChemCatChem 2013, 5, 3289-3298. doi:10.1002/cctc.201300285

31. Kim, S.-Y.; Zhao, P.; Igarashi, M.; Sawa, R.; Tomita, T.; Nishiyama, M.; Kuzuyama, T. Chem. Biol. 2009, 16, 736-743. doi:10.1016/j.chembiol.2009.06.007

32. de Boer, A. H.; de Vries-van Leeuwen, I. J. Trends Plant Sci. 2012, 17, 360-368. doi:10.1016/j.tplants.2012.02.007

33. Hong, Y. J.; Tantillo, D. J. Org. Biomol. Chem. 2015, 13, 10273-10278. doi:10.1039/c5ob01785h

34. Sato, H.; Teramoto, K.; Masumoto, Y.; Tezuka, N.; Sakai, K.; Ueda, S.; Totsuka, Y.; Shinada, T.; Nishiyama, M.; Wang, C.; Kuzuyama, T.; Uchiyama, M. Sci. Rep. 2016, 5, 18471. doi:10.1038/srep18471

35. Meguro, A.; Motoyoshi, Y.; Teramoto, K.; Ueda, S.; Totsuka, Y.; Ando, Y.; Tomita, T.; Kim, S.-Y.; Kimura, T.; Igarashi, M.; Sawa, R.; Shinada, T.; Nishiyama, M.; Kuzuyama, T. Angew. Chem., Int. Ed. 2015, 54, 4353-4356. doi:10.1002/anie.201411923

36. Tomita, T.; Kim, S.-Y.; Teramoto, K.; Meguro, A.; Ozaki, T.; Yoshida, A.; Motoyoshi, Y.; Mori, N.; Ishigami, K.; Watanabe, H.; Nishiyama, M.; Kuzuyama, T. ACS Chem. Biol. 2017, 12, 1621-1628. doi:10.1021/acschembio.7b00154

37. Driller, R.; Janke, S.; Fuchs, M.; Warner, E.; Mhashal, A. R.; Major, D. T.; Christmann, M.; Bruck, T.; Loll, B. Nat. Commun. 2018, 9, 3971. doi:10.1038/s41467-018-06325-8

38. Janke, R.; Görner, C.; Hirte, M.; Brück, T.; Loll, B. Acta Crystallogr., Sect. D: Biol. Crystallogr. 2014, 70, 1528-1537. doi:10.1107/s1399004714005513

39. Driller, R. Structural studies of biotechnologically relevant enzymes. Ph.D. Thesis, Freie Universität Berlin, Berlin, Germany, 2018.

40. Das, S.; Shimshi, M.; Raz, K.; Nitoker Eliaz, N.; Mhashal, A. R.; Ansbacher, T.; Major, D. T. J. Chem. Theory Comput. 2019, 15, 5116-5134. doi:10.1021/acs.jctc.9b00366

41. Aoyagi, T.; Aoyama, T.; Kojima, F.; Hattori, S.; Honma, Y.; Hamada, M.; Takeuchi, T. J. Antibiot. 1992, 45, 1587-1591. doi:10.7164/antibiotics.45.1587

42. Supong, K.; Sripreechasak, P.; Tanasupawat, S.; Danwisetkanjana, K.; Rachtawee, P.; Pittayakhajonwut, P. Appl. Microbiol. Biotechnol. 2017, 101, 533-543. doi:10.1007/s00253-016-7804-1

43. Toyomasu, T.; Tsukahara, M.; Kaneko, A.; Niida, R.; Mitsuhashi, W.; Dairi, T.; Kato, N.; Sassa, T. Proc. Natl. Acad. Sci. U. S. A. 2007, 104, 3084-3088. doi:10.1073/pnas.0608426104

44. Subbarao, G. V.; Nakahara, K.; Hurtado, M. P.; Ono, H.; Moreta, D. E.; Salcedo, A. F.; Yoshihashi, A. T.; Ishikawa, T.; Ishitani, M.; Ohnishi-Kameyama, M.; Yoshida, M.; Rondon, M.; Rao, I. M.; Lascano, C. E.; Berry, W. L.; Ito, O. Proc. Natl. Acad. Sci. U. S. A. 2009, 106, 17302-17307. doi:10.1073/pnas.0903694106

45. Rasoamiaranjanahary, L.; Marston, A.; Guilet, D.; Schenk, K.; Randimbivololona, F.; Hostettmann, K. Phytochemistry 2003, 62, 333-337. doi:10.1016/s0031-9422(02)00551-4

46. Minami, A.; Ozaki, T.; Liu, C.; Oikawa, H. Nat. Prod. Rep. 2018, 35, 1330-1346. doi:10.1039/c8np00026c

47. Whittington, D. A.; Wise, M. L.; Urbansky, M.; Coates, R. M.; Croteau, R. B.; Christianson, D. W. Proc. Natl. Acad. Sci. U. S. A. 2002, 99, 15375-15380. doi:10.1073/pnas.232591099

48. Rynkiewicz, M. J.; Cane, D. E.; Christianson, D. W. Proc. Natl. Acad. Sci. U. S. A. 2001, 98, 13543-13548. doi:10.1073/pnas.231313098
49. Tarshis, L. C.; Yan, M.; Poulter, C. D.; Sacchettini, J. C. Biochemistry 1994, 33, 10871-10877. doi:10.1021/bi00202a004

50. Shishova, E. Y.; Di Costanzo, L.; Cane, D. E.; Christianson, D. W. Biochemistry 2007, 46, 1941-1951. doi:10.1021/bi0622524

51. Aaron, J. A.; Lin, X.; Cane, D. E.; Christianson, D. W. Biochemistry 2010, 49, 1787-1797. doi:10.1021/bi902088z

52. Köksal, M.; Hu, H.; Coates, R. M.; Peters, R. J.; Christianson, D. W. Nat. Chem. Biol. 2011, 7, 431-433. doi:10.1038/nchembio.578

53. Köksal, M.; Jin, Y.; Coates, R. M.; Croteau, R.; Christianson, D. W. Nature 2011, 469, 116-120. doi:10.1038/nature09628

54. Miller, D. J.; Yu, F.; Allemann, R. K. ChemBioChem 2007, 8, 1819-1825. doi:10.1002/cbic.200700219

55. Jin, Y.; Williams, D. C.; Croteau, R.; Coates, R. M. J. Am. Chem. Soc. 2005, 127, 7834-7842. doi:10.1021/ja050592r

56. Shishova, E. Y.; Yu, F.; Miller, D. J.; Faraldos, J. A.; Zhao, Y.; Coates, R. M.; Allemann, R. K.; Cane, D. E.; Christianson, D. W. J. Biol. Chem. 2008, 283, 15431-15439. doi:10.1074/jbc.m800659200

57. Arigoni, D. Pure Appl. Chem. 1975, 41, 219-245. doi:10.1351/pac197541010219

58. Hu, Y.; Chou, W. K. W.; Hopson, R.; Cane, D. E. Chem. Biol. 2011, 18, 32-37. doi:10.1016/j.chembiol.2010.11.008

59. Cane, D. E.; Kang, I. Arch. Biochem. Biophys. 2000, 376, 354-364. doi:10.1006/abbi.2000.1734

60. Baer, P.; Rabe, P.; Fischer, K.; Citron, C. A.; Klapschinski, T. A.; Groll, M.; Dickschat, J. S. Angew. Chem., Int. Ed. 2014, 53, 7652-7656. doi:10.1002/anie.201403648

61. Rabe, P.; Schmitz, T.; Dickschat, J. S. Beilstein J. Org. Chem. 2016, 12, 1839-1850. doi:10.3762/bjoc.12.173

62. Vedula, L. S.; Rynkiewicz, M. J.; Pyun, H. J.; Coates, R. M.; Cane, D. E.; Christianson, D. W. Biochemistry 2005, 44, 6153-6163. doi:10.1021/bi050059o

63. Centeno-Leija, S.; Tapia-Cabrera, S.; Guzmán-Trampe, S.; Esquivel, B.; Esturau-Escofet, N.; Tierrafría, V. H.; Rodríguez-Sanoja, R.; Zárate-Romero, A.; Stojanoff, V.; Rudiño-Piñera, E.; Sánchez, S.; Serrano-Posada, H. J. Struct. Biol. 2019, 207, 29-39. doi:10.1016/j.jsb.2019.04.010

64. Seemann, M.; Zhai, G.; de Kraker, J.-W.; Paschall, C. M.; Christianson, D. W.; Cane, D. E. J. Am. Chem. Soc. 2002, 124, 7681-7689. doi:10.1021/ja026058q

65. Starks, C. M.; Back, K.; Chappell, J.; Noel, J. P. Science 1997, 277, 1815-1820. doi:10.1126/science.277.5333.1815

66. Rabe, P.; Rinkel, J.; Dolja, E.; Schmitz, T.; Nubbemeyer, B.; Luu, T. H.; Dickschat, J. S. Angew. Chem., Int. Ed. 2017, 56, 2776-2779. doi:10.1002/anie.201612439

67. Chen, J.; Li, H.; Zhao, Z.; Xia, X.; Li, B.; Zhang, J.; Yan, X. Mar. Drugs 2018, 16, 159. doi:10.3390/md16050159

68. Yang, B.; Liu, J.; Wang, J.; Liao, S.; Liu, Y. Cytotoxic Cembrane Diterpenoids. In Handbook of Anticancer Drugs from Marine Origin; Kim, S.-K., Ed.; Springer International Publishing: Cham, Switzerland, 2015; pp 649-672. doi:10.1007/978-3-319-07145-9_30

69. Ireland, C.; Faulkner, D. J. J. Org. Chem. 1977, 42, 3157-3162. doi:10.1021/jo00439a010

70. Cai, X.-H.; Wang, Y.-Y.; Zhao, P.-J.; Li, Y.; Luo, X.-D. Phytochemistry 2010, 71, 1020-1024. doi:10.1016/j.phytochem.2010.03.005

71. Bouaïcha, N.; Tringali, C.; Pesando, D.; Malléa, M.; Roussakis, C.; Verbist, J. Planta Med. 1993, 59, 256-258. doi:10.1055/s-2006-959663

72. Ioannou, E.; Quesada, A.; Rahman, M. M.; Gibbons, S.; Vagias, C.; Roussis, V. J. Nat. Prod. 2011, 74, 213-222. doi:10.1021/np1006586 
73. Kobayashi, M.; Nakagawa, T.; Mitsuhashi, H. Chem. Pharm. Bull. 1979, 27, 2382-2387. doi:10.1248/cpb.27.2382

74. Fujiki, H.; Suganuma, M.; Suguri, H.; Yoshizawa, S.; Takagi, K.; Kobayashi, M. J. Cancer Res. Clin. Oncol. 1989, 115, 25-28. doi:10.1007/bf00391595

75. Suganuma, M.; Okabe, S.; Sueoka, E.; lida, N.; Komori, A.; Kim, S. J.; Fujiki, H. Cancer Res. 1996, 56, 3711-3715.

76. Saito, Y.; Takizawa, H.; Konishi, S.; Yoshida, D.; Mizusaki, S. Carcinogenesis 1985, 6, 1189-1194. doi:10.1093/carcin/6.8.1189

77. Saito, Y.; Nishino, H.; Yoshida, D.; Mizusaki, S.; Ohnishi, A. Oncology 1988, 45, 122-126. doi:10.1159/000226545

78. Wahlberg, I.; Eklund, A. M. Dev. Food Sci. 1994, 35, 449-462.

79. Wagner, G. J. Plant Physiol. 1991, 96, 675-679. doi:10.1104/pp.96.3.675

80. Aqil, F.; Zahin, M.; El Sayed, K. A.; Ahmad, I.; Orabi, K. Y.; Arif, J. M. Drug Chem. Toxicol. 2011, 34, 167-179. doi:10.3109/01480545.2010.494669

81. Martins, A. H.; Hu, J.; Xu, Z.; Mu, C.; Alvarez, P.; Ford, B. D.; El Sayed, K.; Eterovic, V. A.; Ferchmin, P. A.; Hao, J. Neuroscience 2015, 291, 250-259. doi:10.1016/j.neuroscience.2015.02.001

82. Thao, N.; Luyen, B.; Brun, R.; Kaiser, M.; Van Kiem, P.; Van Minh, C.; Schmidt, T.; Kang, J.; Kim, Y. Molecules 2015, 20, 12459-12468. doi:10.3390/molecules200712459

83. Ajikumar, P. K.; Tyo, K.; Carlsen, S.; Mucha, O.; Phon, T. H.; Stephanopoulos, G. Mol. Pharmaceutics 2008, 5, 167-190. doi:10.1021/mp700151b

84. Shetty, R. P.; Endy, D.; Knight, T. F., Jr. J. Biol. Eng. 2008, 2, 5. doi:10.1186/1754-1611-2-5

85. Borkowski, O.; Ceroni, F.; Stan, G.-B.; Ellis, T. Curr. Opin. Microbiol. 2016, 33, 123-130. doi:10.1016/j.mib.2016.07.009

86. Salis, H. M. Methods Enzymol. 2011, 498, 19-42. doi:10.1016/b978-0-12-385120-8.00002-4

87. Zelcbuch, L.; Antonovsky, N.; Bar-Even, A.; Levin-Karp, A.; Barenholz, U.; Dayagi, M.; Liebermeister, W.; Flamholz, A.; Noor, E.; Amram, S.; Brandis, A.; Bareia, T.; Yofe, I.; Jubran, H.; Milo, R. Nucleic Acids Res. 2013, 41, e98. doi:10.1093/nar/gkt151

88. Englaender, J. A.; Jones, J. A.; Cress, B. F.; Kuhlman, T. E.; Linhardt, R. J.; Koffas, M. A. G. ACS Synth. Biol. 2017, 6, 710-720. doi:10.1021/acssynbio.6b00350

89. Juhas, M.; Ajioka, J. W. Microb. Biotechnol. 2015, 8, 726-738. doi:10.1111/1751-7915.12296

90. Juhas, M.; Ajioka, J. W. PLoS One 2015, 10, e0123007. doi:10.1371/journal.pone.0123007

91. Tantillo, D. J. Angew. Chem., Int. Ed. 2017, 56, 10040-10045. doi:10.1002/anie.201702363

92. Hare, S. R.; Tantillo, D. J. Beilstein J. Org. Chem. 2016, 12, 377-390. doi:10.3762/bjoc. 12.41

93. Tantillo, D. J. Nat. Prod. Rep. 2011, 28, 1035-1053. doi:10.1039/c1np00006c

94. Dixit, M.; Weitman, M.; Gao, J.; Major, D. T. ACS Catal. 2017, 7, 812-818. doi:10.1021/acscatal.6b02584

95. Weitman, M.; Major, D. T. J. Am. Chem. Soc. 2010, 132, 6349-6360. doi:10.1021/ja910134x

96. Xu, M.; Wilderman, P. R.; Peters, R. J. Proc. Natl. Acad. Sci. U. S. A. 2007, 104, 7397-7401. doi:10.1073/pnas.0611454104

97. Leferink, N. G. H.; Ranaghan, K. E.; Karuppiah, V.; Currin, A.; van der Kamp, M. W.; Mulholland, A. J.; Scrutton, N. S. ACS Catal. 2018, 8, 3780-3791. doi:10.1021/acscatal.8b00692

98. Miller, D. J.; Allemann, R. K. Nat. Prod. Rep. 2012, 29, 60-71. doi:10.1039/c1np00060h
99. Ansbacher, T.; Freud, Y.; Major, D. T. Biochemistry 2018, 57, 3773-3779. doi:10.1021/acs.biochem.8b00452

100. Freud, Y.; Ansbacher, T.; Major, D. T. ACS Catal. 2017, 7, 7653-7657. doi:10.1021/acscatal.7b02824

101. Major, D. T.; Freud, Y.; Weitman, M. Curr. Opin. Chem. Biol. 2014, 21 25-33. doi:10.1016/j.cbpa.2014.03.010

102. Major, D. T. ACS Catal. 2017, 7, 5461-5465. doi:10.1021/acscatal.7b01328

103. Görner, C.; Hirte, M.; Huber, S.; Schrepfer, P.; Brück, T. Front. Microbiol. 2015, 6, 1115. doi:10.3389/fmicb.2015.01115 104. Rinkel, J.; Steiner, S. T.; Dickschat, J. S. Angew. Chem., Int. Ed. 2019, 58, 9230-9233. doi:10.1002/anie.201902950

105. Oberhauser, C.; Harms, V.; Seidel, K.; Schröder, B.; Ekramzadeh, K.; Beutel, S.; Winkler, S.; Lauterbach, L.; Dickschat, J. S.; Kirschning, A. Angew. Chem., Int. Ed. 2018, 57, 11802-11806. doi:10.1002/anie.201805526

\section{License and Terms}

This is an Open Access article under the terms of the Creative Commons Attribution License (http://creativecommons.org/licenses/by/4.0). Please note that the reuse, redistribution and reproduction in particular requires that the authors and source are credited.

The license is subject to the Beilstein Journal of Organic Chemistry terms and conditions: (https://www.beilstein-journals.org/bjoc)

The definitive version of this article is the electronic one which can be found at: doi:10.3762/bjoc. 15.228 